\title{
Article \\ The Nefarious Hierarchy: An Alternative New Theory of the Firm
}

\author{
Richard J. Arend $\mathbb{C}$
}

Citation: Arend, Richard J. 2021. The Nefarious Hierarchy: An Alternative New Theory of the Firm. Administrative Sciences 11: 21. https://doi.org/ 10.3390/admsci11010021

Received: 26 January 2021

Accepted: 20 February 2021

Published: 26 February 2021

Publisher's Note: MDPI stays neutral with regard to jurisdictional claims in published maps and institutional affiliations.

Copyright: (C) 2021 by the author. Licensee MDPI, Basel, Switzerland.

This article is an open access article distributed under the terms and conditions of the Creative Commons Attribution (CC BY) license (https:// creativecommons.org/licenses/by/ $4.0 /)$.
Department of Business Administration, University of Southern Maine, Portland, ME 04104, USA; richard.arend@maine.edu

\begin{abstract}
We propose a new theory of the firm based on the premise that 'the firm' characterizes a factor-integrative form of doing business that is often the most effective and efficient structure for doing well by doing bad. We define the terms and requirements involved for such a theory, and fulfill those requirements by explaining what it is 'to do bad', and why and when the firm form is especially fitted to that. We do so by building upon basic premises about 'bad-ness' and by leveraging the logic of market failures. From this base, we argue a new reason for the firm form to exist and yet be limited in its growth. This leads to six related propositions regarding the relationships between 'bad' firms, tolerant contexts and realized social harms. We discuss how to test the ideas, and what the implications are for research on the firm, strategy and entrepreneurship.
\end{abstract}

Keywords: theory of the firm; nefariousness; ethics; governance choice/ form; firm performance differences; entrepreneurship

\section{Introduction}

Bad exists. There is 'bad' demand (e.g., for destructive, addictive drugs). There is 'bad' behavior (e.g., in abuses of market power; in rent-seeking). The point of this paper is to argue for a new Theory of the Firm (Tot F) based on the firm-as-a-governance-form being relatively better for doing well by doing bad, under many but not necessarily all-important business contexts. For example, the 'firm' is a managerial and coordinative economic form that is relatively better than alternatives such as the spot market for supplying 'bad' demand, for conducting 'bad behavior', for increasing 'bad' returns, and for avoiding the penalties for doing all of that 'bad' stuff. The initial working hypothesis for our mostly deductive argumentation that follows is that the firm form, given its track record of being used as a tool for perpetrating significant social harms, is often relatively better at so doing and that that role constitutes one of the reasons for its continued existence.

As yet, no one has proposed a TotF based on morality-in this case on the social value of business - and so we attempt to fill that gap formally here. We do so because it is important, especially now in the age of existential threats over the environment, disinformation wars, inequality, and class warfare that all connect to businesses. It is vital that we recognize explicitly that this governance 'tool', like any other tool, can be used for 'bad', and often is. Given that recognition, we can then move to better understand how to identify the factors involved in order to mitigate the harms. We contribute to the literature by providing a comprehensive analysis of this proposed new TotF and several subsequent propositions, in addition to discussing the important implications.

We acknowledge that we are not the first to identify the real and theoretical harms that firms and 'forms' of firms do (e.g., through hierarchical criminal enterprises or pyramid schemes). We also acknowledge that it is the user of the form that is mostly to blame for its harm-such users often labelled as 'dark side' entrepreneurs and managers (e.g., Elert and Henrekson 2016; Lucas and Fuller 2017; Webb et al. 2009). The rest of the blame goes to the form itself; it is just too easy to scale up such harms, while avoiding responsibility, through the firm form. Recognizing that, we move forward as the first to argue that one of 
the reasons that the firm exists is that its operational form is superior to alternatives for doing harm in blind pursuit of creatively increasing private wealth, power and prestige (Baumol 1990).

The idea that firms can do social harm is an important area to theorize over for many reasons, including: the reality that firms conduct the majority of economic activity in an economy and so the damages that they can do have a significant societal impact; the practical concern that firms that are not harmful may still have to compete against those that are, and so will need to understand them; and, the academic responsibility that if we neglect the dark sides of business, then we neglect the opportunities to remedy the issues both within firms and within their institutional contexts, including how to identify likely culprits and dissuade them through policy recommendations (e.g., Hmieleski and Lerner 2016; Lundmark and Westelius 2019).

Our main objective is to argue that such a dark description of the firm meets the main criteria to be considered a new TotF. To accomplish that, we first provide the necessary definitions of the main terms. We then specify the standard criteria to be a new TotF and argue that our new TotF satisfies those criteria. We then build a set of propositions about firm incentives and contextual tolerance for privately profitable social harm, and discuss what such a new TotF means for various significant stakeholders of a firm.

\section{Materials and Methods}

The materials and methods reflect that this is a theory-building rather than a theorytesting paper. Our materials are the terms we define and the literature from which we draw. We rely on deduction as the main method for building the new TotF from the materials.

\subsection{Definition of Terms}

We define the main terms involved in arguing our proposed TotF, beginning with what we mean by a 'firm'. The operational form of the firm is commonly understood as a legal entity, a transactional organization, a hierarchical structure, and a common, significant tool for conducting commerce. In the TotF literature (e.g., Conner 1991), the firm is an integrator, embodying joint production, and the owner of the rights to productive services of multiple inputs (Alchian and Demsetz 1972). The common portrayal of the firm is as a separate entity with several advantages over other legal forms of conducting business; advantages such as limited liability, infinite life and the ability to issue shares. From a technological perspective, the firm is an organizational form that is used to capture synergies across different units to realize efficiencies and economies in production (Tirole 1988). The firm is also a form of social grouping with its own identity and focus. It is a governance form taking many variants of ownership, size, structure and liability, used as a tool to pursue the common objective of increasing wealth, power and prestige for at least the entrepreneurmanager making the decisions. Here, the idea of the firm as a legal and organizational form focused on profit maximization stays constant, but the idea that such maximization is aligned with the public's benefit is challenged. This is because, like any other business tool, the firm can be used for good or bad or both by the people managing it (e.g., Matten et al. 2003; Oh et al. 2017).

A TotF explains and predicts a firm's economic existence. This is usually accomplished by leveraging its differences relative to alternatives like the spot market (e.g., Grant 1996). To be clear, there is no single, multi-purpose TotF. Each is an abstraction designed to address particular set of its characteristics and behaviors. Thus, many TotFs exist simultaneously, offering complementing and competing explanations of the same phenomena (Grant 1996). As such, there are many reasons why firms are thought to exist (e.g., Conner 1991). Thus, any one TotF does not rule out the legitimacy of any other TotF. Instead, alternative TotFs help fill out the multi-dimensional nature of the complex and varied forms that firms take. Given this understanding of TotFs, our proposed reason for the firm form existing does not imply this is the only reason. However, it does provide an explanation for why 
some socially harmful activities are indeed carried out through this form of economic organization.

There are several requirements that a proposed TotF must meet. For example, Holmstrom and Tirole (1989, p. 65) require that a TotF explains why firms exist, and why a firm is limited in its scale and scope. These requirements have been interpreted as: (i) the need to explain why the firm form is better at a specific purpose than the alternative of contracting in the spot market (This only means that the firm is best in some important economic circumstances than alternatives and not that it must always be best. Transactions also occur in spot markets and in governments, but the TCE remains a TotF because it explains when firms are better); and, (ii) the need to explain why firm growth is bounded in that role. Other suggested requirements include: providing an explanation for firm resource and performance heterogeneity; explaining why different organizational forms, including 'hybrids' (e.g., joint ventures) exist; and, specifying empirical tests that are expected to help verify the arguments supporting the TotF.

A social harm occurs when there is a net cost to the focal socio-economic system. Doing bad creates social harms. Costs are evaluated in 'financial' and 'human utility-based' terms over time. Damage is done not only in economic ways (e.g., resources wasted) but also in social ways (e.g., increased injustice, inequity, and sorrow). Like any other outcome, we expect to see more social harm when the private benefits to doing it rise or the associated private costs and risks fall. Note that our focus on harms involves taking a different scientific mindset. Specifically, it means that a 'business action' - a commercial transaction-is not simply assumed to be 'neutral'. Instead, we must care about whether it has good or bad socio-economic consequences, and not just about whether it can be made more efficient solely in terms the directly affected parties' private costs.

A market failure occurs when 'free' (i.e., unregulated) structures-specifically, those that allow buyers and sellers to voluntarily exchange any type of goods, services or information-do not reach a Pareto efficient outcome (i.e., a state in which resources cannot be rearranged to make one party better off without making at least one party worse off). Market failures that can and do produce harms include negative externalities, abuses of market power, information asymmetries, and the overuse of public goods.

\subsection{Related Literature}

Our proposed TotF has not been described before, but the use of the firm as a harmful device has been alluded to prior (e.g., Orts 1998; Palmer et al. 2016). Bain (1954) and others (e.g., Lundmark and Westelius 2019) have detailed several nefarious purposes to which firms have been put, including monopoly pricing, corruption (through bribery), tax evasion, exploitation of foreign workers, and erosion of social cohesion. The firm, as an integrator-of-operations, allows for the concealing of illegal or immoral behavior. For example, "the internalization of transactions within a firm is a way of concealing practices deemed illegal" such as price discrimination (Tirole 1988, p. 16). The nefariousness of firm behaviors that inspired Bain (1954) and the US Clayton and Sherman Acts prior, focused on monopolistic-oligopolistic, collusive, anti-competitive abuses of market power to restrict supply and increase prices in order to earn super-normal rents. Given it is impossible to avoid overlap with issues of market power (and governmental reactions to that power) when considering the potential 'bad' actions of firms and why that form of governance is particularly effective at them, it is no surprise that our proposed TotF subsumes some of the issues covered by Bain (1954) and others.

The use of the firm as a destructive tool has also recently been a topic in the entrepreneurship (ENT) literature. While relatively young in years, ENT research is quite mature in the subject matters it publishes, being unafraid to highlight the more challenging and less comfortable subjects, such as dark side issues. Explicitly identified, exemplified and analyzed seriously by Baumol (1990), the idea of unproductive and even destructive ENT activity has been a significant subject area in the ENT literature recently (e.g., Arend 2015; Elert and Henrekson 2016; Lucas and Fuller 2017; Webb et al. 2009; Zahra and Wright 2016), 
although considered in various forms by economists and others prior (e.g., Bain 1951; Schumpeter 1934). Such harmful economic activity has been labelled antisocial, evasive, renegade and even wicked.

The literature related to our topic not only includes descriptions of the firm form being used for doing well by doing bad, but also includes aspects of several alternative TotFs. While other TotFs have assumed that agent rationality aligns with doing 'good' because decisionmakers have incentives to follow positive behavior (e.g., due to threats from competition, monitoring or replacement), we do not assume that alignment here. This is because other opportunities, like colluding over 'bad' deeds (e.g., to violate safety regulations), may remove such discipline normally imposed by competitors or regulatory monitors. As such, our proposed TotF differs from past well-intentioned ones. Those TotFs focused on wealth creation rents (e.g., Ricardian and entrepreneurial) while ours focuses on wealth shifting (e.g., rent-seeking) and net wealth destruction. As such, past TotFs are based on different premises and boundaries.

Given we are seeking to explain a rational but flawed use of the firm form, a behavioral view is assumed (e.g., Cyert and March 1963). For example, leaders can influence firm actions in socially beneficial or harmful ways (e.g., Al-Shammari et al. 2019; Lovelace et al. 2018; Petrenko et al. 2016). Their abilities, experiences and incentives can affect their decisions over their ventures' product liabilities, and other social and competitive risks undertaken (e.g., Ball et al. 2018; Connelly et al. 2010; Lim and McCann 2013). More broadly, the bounded rationality, satisficing, and attempts to avoid uncertainties through routinization occurring in real firms often provide opportunities to not only directly do well by doing bad but also indirectly - though creating temporary periods of chaos that can be exploited by self-serving agents (e.g., Cohen et al. 2012) (One behavioral reaction to 'getting caught doing bad' has been in the form of attempts to improve public relations; and, corporate social responsibility (CSR) has been one result (e.g., Lange and Washburn 2012). This important relatively recent stream of literature considers ways that firms can do better for its many stakeholders, including its communities and the environment (e.g., Ashrafi et al. 2020). That steam also explores the measures used to assess (ir)responsibility and how the mostly voluntary and unaudited reporting can be abused (e.g., Michelon et al. 2015), as though 'greenwashing'. But, CSR is not a TotF, nor does it focus on the firm form as a tool for doing bad; it mostly focuses on how to improve the firm doing good and how CSR practices can help that without hurting it doing well. As such, the CSR literature has some relevance to our discussion of ways to improve firm behavior after we have argued that one reason the firm form exists is to do well by doing bad.).

\section{A New Theory of the Firm}

We now make our case for our alternative TotF, drawing on the definitions of our main terms, on the specification of the necessary requirements, and on the ideas established in the relevant background literature. We propose that the firm exists because it is often the best form of organization for doing well by doing bad. The firm form is simply relatively more effective and efficient for coordinating illegal or immoral activities, for managing those activities through oversight, cultural pressure and whistle-blower retaliation, for hiding responsibility from authorities when exposed, for realizing scale economies across those activities, and for dehumanizing victims. Fortunately, the firm form is limited in its scale and scope by several factors.

We build this TotF from premises and logics in order to fulfil the two necessary requirements and then to generate six related propositions. We begin by exploring how firms can be used for doing well by doing bad based on market failure logics and on the premise that rent-seeking is a viable basis for economic performance. We then analyze why the firm form is relatively better at such activities, drawing on and extending concepts from existing TotFs. From this basis we can then address the two necessary requirements for a TotF: explaining why the firm form is superior to alternatives, and explaining why it is nonetheless bounded in its growth. That work leads to a set of summary propositions about 
the 'bad' firm, its context, and potential interdependent effects in terms of the realized social harms.

\subsection{Doing Social Harm (by Exploiting Market Failures)}

Firms are used for 'doing bad' in many ways-ways that produce private profit without sufficient care about public costs (Baumol 1990). Table 1 describes many of these ways. For example, a firm can be used to fill socially 'bad' demand, exacerbating an existing negative externality. Such firms-such renegade, destructive ventures (Webb et al. 2009) —often supply 'sin' items (e.g., Cai et al. 2012), as dark web sites like Silk Road, or as organized criminal entities in the physical real world, have done and continue to do.

Table 1. Forms of 'Bad' Acts that Generate Private Benefits with Social Harms.

\section{Exacerbating Negative Externalities (Not Paying the Full Cost of the Product) More Than Other Firms}

- $\quad$ Abusing market power (e.g., to manipulate pricing).

- $\quad$ Exploiting public goods more than other firms (over-using common property for private gain).

- $\quad$ Rent-seeking (e.g., lobbying to restrict supply, to block entry) and regulatory capture.

- Use of deception and fraud to over-charge buyers.

- $\quad$ Cheating to cut costs (e.g., skirting employee safety measures; using sub-par inputs).

- $\quad$ Stealing (IP) to cut costs.

- $\quad$ Bribing/ threatening/ blackmailing to obtain favorable terms and orders.

- $\quad$ Supplying 'bad' demand (e.g., illicit drug-dealing) [and with premium pricing].

- Market-making in the 'task' economy to commoditize others while skirting safety/ health/ training/ maintenance/ employee benefits/ minimum wage regulations.

Note: 'social harm' can be considered in several ways-the market failures listed entail that there exists an economic loss in terms of Pareto efficiency; besides the financial losses from those failures and from rent-seeking, there can also be non-financial losses in terms of trust (in markets, or in the institutions overseeing them), and in terms of injustice.

Other demand-driven, socially harmful, negative externality-exacerbating functions are taken on by firms. One involves providing restricted-supply-by-design 'image' goods. These wasteful goods may serve some purpose of signaling wealth, but the practical value of them is most often a fraction of the price, and the management of their supply chain is often unsavory. Perhaps the diamond market managed by De Beers is the worst case, given the horrors often associated with it, such as the human costs for conflict gems. Another function involves exploiting 'greed' by providing pyramid schemes (e.g., Ponzi; Madoff) or false promises (e.g., Theranos; $B r e-X$ ) that attract money that is simply redistributed rather than being honestly invested to produce new value. Participant-buyers know either that the expected returns are too good to be true, or know that getting in early can translate into 'easy money'. Such schemes merely move money around, destroying net value. Many of these multi-level marketing firms look entrepreneurial (Baucus and Mitteness 2016), often promising their recruits the benefits of high-powered incentives without the risksthrough being looked after by a community (e.g., Mary Kay; Herbalife). These appear to be Machiavellians appealing to other would-be Machiavellians (Hmieleski and Lerner 2016).

The firm form can also be used to 'make markets' that not only exacerbate negative externalities but also allow the abuse of market power. These firms commoditize their suppliers while exploiting safety regulations and other codes that protect civil society and the environment. These include firms that effectively flout the spirit if not the letter of the law, at scale, through Internet-based technology, to exploit the 'sharing economy'. While such regulation-evasive entrepreneurial activity (Elert and Henrekson 2016) may 
offer some 'good' by connecting supply to demand, unfortunately, the bad involved often outweighs the good to at least one party. Consider the creative high-speed trading scheme that used fast computer algorithms that secretly and risklessly (but legally) exploited client instructions to brokers in order to profit from that information prior to actually carrying out those trades (Lewis 2015). Consider the sidestepping of safety and quality regulations by Internet-based sharing brokers like Uber. In this arbitrage role (Kirzner 2009), the parties with the least bargaining power and information are disproportionately exploited, while the rich holders of under-used but sharable assets are further enriched, tearing the social fabric further.

The large scale made possible through the firm form - a form that often involves an authoritative hierarchical structure efficiently managing levels of specialists- has often been used to build and exploit market power. The big firm becomes a price-maker rather than a price-taker, resulting in dead-weight economic losses from prices being set well above an efficient level. Such firms strip profitability from suppliers, and reduce incentives for socially beneficial product innovation. Additionally, if such firms should be so poorly managed (e.g., by taking on excessive risks, say, pre-2008) so as to fail, the scale involved (e.g., relating to potential impacts on the economy in terms of job loss, brand loss, and other influences) often results in political connections providing bail-outs, at sizable harms to the rest of society (e.g., $A I G$ ).

Relatedly, the firm form, due to its scale, scope and associated political influence, has often been used in rent-seeking-i.e., obtaining wealth through re-allocation rather than creation. Often this is done legally and transparently-through political lobbying for protection and for subsidies (e.g., Harley-Davidson). Sometimes this is legal but less-thanlegitimate (e.g., abusing the court system with malicious lawsuits to reduce competition or to take advantage of squatting, for example, through patent or Internet-registration trolling). Additionally, sometimes this is done illegally, through bribery, blackmail and other forms of coercion, often where size does matter for appearing as a bigger threat.

Rent-shifting can also occur simply through 'cheating', by displacing a better firm that would have 'won' (e.g., a contract) if everyone had played by the rules. This can be legal-but-unethical or simply illegal in nature, even when the contest is over a legal and legitimate commercial business opportunity. Managers use their firms to gain a performance advantage through cheating in many ways, including acting to: collude to fix prices, tacitly or otherwise; 'capture' regulators to ease enforcement; price discriminate; price predatorily; vertically foreclose markets; bribe; falsely advertise; abuse workers; deceive testing (e.g., $V W$ ); creatively account in order to evade paying fair taxation and accurate scrutiny (e.g., Enron); engage in deceptive practices in the supply chain; fail to disclose hidden costs and dangers and invasions of privacy to consumers (e.g., Facebook); apply undue political pressures to avoid legal product liability; and, prey on the weak. There is no shortage of organizations taking on this role, especially when the company's managers are highly rewarded, feel temporarily under duress, or have reached their positions because of their narcissism, psychopathy and Machiavellianism that they have then imprinted as acceptable traits to display to their own firm's employees (Hmieleski and Lerner 2016).

Besides cheating rivals, the firm can engage in cheating customers, partners and investors by perpetrating frauds through exploiting informational asymmetries. Inefficiencies posed by adverse selection, in misrepresenting quality (Akerlof 1970), and by moral hazard, in misrepresenting effort, generate social harms. For example, this occurs when firms mislead consumers about the value-level of their wares by misrepresenting their features or by failing to disclose their faults (e.g., Ford's Pinto; Monsanto's Round-Up; Big Tobacco's links to cancer).

Additionally, to complete the set of ways that managers can use firms for doing well by doing bad through leveraging market failures, the firm form can also be used as an effective means for over-exploiting public goods. Conglomerates, and especially multi-nationals, have over-fished international waters, over-drawn from shared clean water sources, over- 
taxed public infrastructure, over-indulged in bail-out financing (e.g., in 2008 and 2020 in the US), and generally over-mined poorly defined property rights (e.g., of personal data, where scale does matter, for example, in feeding data to machine-learning algorithms to better predict and influence consumers for a firm's private gain).

\subsection{Addressing TotF Requirement \#1: Explaining Why the Firm Form is Better}

We started with several basic premises: that 'bad' exists (e.g., in demand for illegal goods); that it is tolerated (e.g., in the US there is 'unlimited' private money for influencing public policy); and, that it can be profitable (e.g., to charge monopoly prices). Additionally, we applied economic logic (e.g., of market failures) and behavioral assumptions (e.g., of bounded rationality) to depict the range of social harms made possible by using firms as tools. We now describe why firms are relatively better in doing well by doing those bads. We describe how the firm provides a form of organization that can be used to do them for less cost and at less risk, and often with more benefits. Table 2 summarizes many of those advantages described below.

Table 2. Illustrative Advantages from the Firm Form in Doing ‘Bad' Activities.

Size-related: the firm form (e.g., as a hierarchy of authority-based-controlled, coordinated specialists with long-term buy-in, shared access to specialized assets, risk-sharing, repetition) can achieve greater size and diversity more efficiently and effectively than a set of spot market contracts:

- Economies of Scale-reduce the average costs of the activities over any one output (e.g., by sharing specialized assets like 'legal' or 'accounting' or 'security' or 'brand')

- Economies of Scope-reduce the average costs of the activities over related outputs (e.g., by using one opened up distribution channel to push related and complementary products, like different kinds of illegal drugs)

- Bargaining Power-reduces the amount of 'financial value' the firm gives up to other parties

- Threat-increases the power and scope from which to threaten internal and external parties (to coerce them into firm-favorable decisions), and increases the stakes involved (making defense of the firm/ brand likely and devastating to any smaller 'attacker')

- Tullock Paradox-extend the low cost of bribery relative to its benefits

- Increased Likelihood of Regulatory Capture-with sophistication and specialization accompanying scale comes increased dependence of regulators on firm-controlled expertise, monitoring, and measuring

- (Positive) Spillover Capture-with scale and scope, internalization is likely to increase the appropriability of any 'financial value' created by the firm

Central Authority-related: the firm form (e.g., as a set of long-term contracts where residual rights are held by the firm, and coordination comes from firm-authorized directions rather than negotiations) can achieve tighter coordination, consistency, and complexity and loyalty than a set of spot market contracts:

- Secrecy and Opaqueness - reduces the accountability of those at the top of the hierarchy, and strengthens their (image of) power and infallibility.

- Loyalty-increases threat to insiders (whistle-blowers, mutineers) who would expose wrong-doing (that would increase costs to the firm) or try to privately gain from its activities (that increase the costs of opportunism and politicking); increases ability to threaten outsiders as well (where ethics would be displaced by identity)

- Coordination-reduces costs from miscommunications and misconnections; keeps stories/ messages straight when questioned by any authorities

- Complexity-reduces costs of complicated processes through specialization

- Brand-having 'one voice' builds some form of trust in the products across the size (geographic) and scope (variety) dimensions (reducing advertising and introduction costs)

\subsubsection{Lower Costs}

The firm form can do 'more well' —increase its private gains_-by doing bad 'more efficiently' - by lowering its costs of harming others. The same logics from micro-economics and strategy can be applied to argue that the firm form reduces many transactional expenses 
(e.g., repeated contracting costs; specialized asset hold-up issues) while also improving specialized knowledge coordination and monitoring effectiveness (e.g., Williamson 1979; Grant 1996) in 'doing bad'. Other cost efficiencies that the firm form provides are based on the same mechanisms underlying the standard technological view, the market power view, and the resource-based view (RBV_ e.g., Wernerfelt 1984) (The same underlying mechanisms for the firm form's superiority over the spot market apply (e.g., greater leverage of immobile factors, and reduced spillovers) as in the RBV-based TotF, but in our TotF, those mechanisms lead instead to improved rent-shifting, fraud, regulatory and tax avoidance and evasion, unfair competitive practices, and so on.) where the focus has been on firms producing goods rather than bads.

Therefore, here, instead of the assumption that the focal contracts and outputs are socially beneficial, the assumption here is that they are socially harmful. Note that the same logic applies for explaining the efficiencies gained by using the tool of a hierarchy rather than the spot market. The same logics apply regarding the possibilities of reduced transaction costs, of increased efficiencies from scale and scope economies (e.g., based on learning curve effects and shared overhead possible across immobile and scarce factors) located within the boundaries of a large and diversified firm, and of cost-reducing innovations arising from close on-going partnerships with (non-spot) suppliers. Gaming and Ponzi schemes, in fact, are based on diversifying risk and on scaling up the pyramid efficiently in order for those who control, or start, the scheme to better profit at society's expense. Enron relied on its size and market-based efficiencies to not only help deregulate energy markets but then to also strategically shift energy supplies to harm consumers; feats that some collection of individual spot-market entities could not have accomplished as quickly, surreptitiously, or with such concentrated private gains.

\subsubsection{Lower Risks}

The firm-as-a-tool can help managers reduce risks by helping them personally avoid any punishments associated with 'doing bad'. This, unfortunately, makes such activities even more likely (Cressey 1973). Such risk-reduction is possible because the firm form has characteristics useful for evading the detection of law-breaking, for lowering the costs when caught, and even for rationalizing the harmful activities to oneself and to others.

The firm form makes it harder to get caught 'doing bad'. Inside of an authoritative hierarchy, especially one with a strong culture and leader, it is easy to filter out, delegitimize, or intimidate and isolate any potential whistleblowers. Firm size and complexity increase the difficulties for doing outside monitoring. The firm's culture, identity and authorityrelated incentives can be exploited to (non-explicitly) push employees to cut corners regardless of the formal rules, especially when the culture is set by founders who exhibit dark-triad, imprintable behaviors (Hmieleski and Lerner 2016) (Top administrators are very savvy in putting forth 'ethical' guidelines and trainings that are documented and then even signed by employees in a formal manner, all the while informally-through culture and incentives-pressuring employees to 'do anything' to meet the numbers, and turning a blind eye to violations until someone is caught, at which point the formal documents cover them but not the employees. Such behaviors are not uncommon (e.g., noted in firms from Enron to $V W$ to Boeing)). Tournament-style pay-promotion systems-something not available in spot markets - can be used to incentivize risky covert tactics that increase firm profits while also filtering out less-corruptible employees. Regulatory capture is more likely with the scale and secrecy that a firm can wield, reducing the likelihood of being charged with crimes (e.g., Pai and Tolleson 2012). The firm form provides further riskreduction when its operations cross borders, as internationalization makes the firm much more opaque to any national investigation, and much easier for pursuing activities like hiding bribes, evading and avoiding taxation, and partaking in unsafe or high-pollution processes (e.g., by shifting them to where regulations are weaker). Relative to a set of supply-chain contracts, the firm form allows interaction agreements involving much less 
specificity, and that interpretive ambiguity has advantages in hiding illegal activity, or at least in making it difficult to prove in criminal courts.

The firm form also makes it easier for managers to avoid responsibility when caught. This is because that form of organization entails more informal and fluid internal relationships, allowing blame to be avoided or shifted downwards. Plausible deniability is more easily embedded within a hierarchy than within a set of precise legal contracts in a spot market. Firms, rather than individuals in open contract markets, are more likely to have powerful lawyers and well-connected board members who may find it worthwhile to help executives escape prosecution for bad deeds occurring under their oversight. Additionally, from a 'shifting responsibility' perspective, the firm form is quite effective-as it is relatively easier to 'trap' employees into being loyal scapegoats than more skeptical spot market suppliers. Executives in the firm can use hierarchical authority, or financial rewards, or even identity-based pressures, to push employees to do their harmful bidding or even ready them to be cannon-fodder; tools collectively that alternative transactional forms cannot draw upon.

Finally, the firm form makes it easier to get other corrupt entities involved in bad deeds in order to reduce the risk of exposure. The scale, scope and span available uniquely through the firm form increases the variety and secrecy of the set of attractive perks that can be dangled to colluding partners, in the forms of: insider information; backdated options (e.g., as alleged at Apple); privileged use of company resources; monetary bribes; and, other often hard-to-track favors. Such perks may even be easier to justify in firms exhibiting a global impact and a greater entrepreneurial orientation (e.g., in the proclivity for greater risk-taking and aggression-Lumpkin and Dess 1996).

\subsubsection{Higher Benefits}

Besides lowering the costs and risks of (doing well by) doing bad, the firm form offers several ways to increase the 'doing well' part. First, firms benefit more from scale; for example, through the mechanics of the Tullock paradox, where relatively small bribes provide access to very large project profits. Second, firms benefit more from scope; for example, it is relatively easier to expand into blackmail and favor-trading with a target once they have been supplied some illegal substance by the firm. Third, firms benefit from related innovation; for example, the firm form's superior information flows and coordination mechanisms can give rise to new opportunities to do 'bad', by accessing susceptible partners' partners, by extorting more from existing marks, and by identifying synergies across 'bad' activities. Fourth, firms benefit more from their greater influence on events; a firm form's more concentrated and concealable power can generate opportunities to shape the 'bad' activities. This shaping can occur through lobbying for new loopholes, lobbying to pre-empt restrictive regulations, or lobbying to delay new property rights over information privacy, or though exploiting new technologies at scale prior to their public exposure (as in the case of high-speed trading).

Size matters when the outcome is social harm. The scale and types of societal harms made possible through the tool of the firm are dependent on the kinds of economies not available through alternative forms of organization. Larger firms can be used to steal intellectual property from weaker partners, or even force their demise, through the exercise or threats of scale-related bargaining power, legal resources (e.g., applied to frivolous lawsuits), price-war-related war-chests, predatory hiring of a target's managers, and vertical foreclosure (e.g., Arend 2006). Through the Citizens United ruling in the US, and through bribery and influence over worker voting in other countries, larger firms have an effective way of shaping law-making, often secretly, to tilt the competitive playing field (e.g., through tariff protections) towards their own private gains but at sizable public losses. The firm form provides better scaling of opportunities that exacerbate negative externalities, allowing firms to profit more by not having to pay the true costs of their polluting waste or of their exploited labor (e.g., allegedly as in the case of Wal-Mart- $\mathrm{O}^{\prime}$ Connor 2014). Additionally, the greater levels of complexity possible in the larger firm allow for the 
manufacture of informational asymmetries, specialized expertise and causal ambiguities that can be exploited against others. For example, such complexities can be abused to create specialist-based regulatory capture, to obfuscate labor-exploiting subcontracting and sourcing, and to hide taxable income and excessive risk-taking.

In sum, the firm form provides lower costs, lower risks and higher benefits for doing well by doing bad. Based on this economic logic, then, we have satisfied the first necessary TotF requirement- that the firm form is superior to alternatives, in sufficient cases, for doing this one focal thing-i.e., profitably being 'bad'. The firm form has advantages in providing information-based coordination and integration where the spot market cannot (i.e., spot markets suffer from risks of expropriation by 'outside' individuals due to the characteristics of the knowledge involved). It is a more effective form for keeping secrets that the spot market cannot match. It is a more efficient form for dealing with complex and uncertain transactions because its long-term contracts, and the related authoritarianism, work better to cover undesirable contingencies, such as threats from outside investigations. It is a more efficient form for exploiting scale and scope economies than temporary sets of spot market agreements. Additionally, it is a much more secure means of ensuring loyalty, opaqueness and continuity (internally if not externally) than spot market contracting.

\subsection{Addressing TotF Requirement \#2: Explaining Why the (Bad) Firm Is Limited in Growth}

We now argue that there are limits to any one firm's growth in 'doing bad'. Those arguments support our contention that our proposed TotF meets the second necessary requirement for so being.

At the conceptual level, a firm that is growing by doing bad is limited by the size of its pool of victims-i.e., the parties that it is 'doing bad' to. The firm must eventually bump into that limit when pursuing rent-shifting and rent-seeking activities. With such activities, a firm does not have pure consumers of value in some 'expanding pie' context; instead, it has victims in a 'fixed pie' or a 'shrinking pie' context. Thus, the firm reaches its size limit of headcount at the point where hiring the next person is too costly because she is worth more as an outside victim than as an inside employee.

When engaging in alternative 'bad' activities-that are not pure rent-seeking or rentshifting - the firm confronts other such limits to growth. For example, there is a theoretical limit in supplying illegal goods that occurs when the market is saturated, the product kills off the demand, or regulators can no longer ignore the social costs and must act against the firm. There is a theoretical limit to a Ponzi scheme that occurs when there are not enough new recruits (aka 'suckers') left to pay fees upwards to sustain it. There is a theoretical limit to the worker-exploiting market-maker that occurs when sufficient numbers of workers unite and revolt (e.g., in democracies where they have the power to persuade regulation against the firm), or when demand is satisfied for the dwindling few not being exploited. There is a theoretical limit to exacerbating negative externalities that occurs when the damages become so big as to be noticed and regulated, or when the target being harmed is ruined beyond further capacity for abuse. There is a theoretical limit to exploiting market power that occurs when the deadweight loss becomes too much in the economy not to be noticed and regulated, or when the inflated price self-imposes output restrictions that limit production capacity. Additionally, there is a theoretical limit to over-exploiting public goods that occurs when this becomes so great as to be noticed and protected, or when these goods are simply exhausted.

A firm being used for 'bad' will also be limited in its growth through the usual diseconomies of scale and scope. Such diseconomies arise from several potential sources, including: the loss of information and control that increases as the hierarchy grows; cannibalization across activities; duplication of efforts; decreasing coordination from increased in complexity arising from greater size and diversification; loss of focus; infighting over resources; rising monitoring costs; the exacerbation of cognitive and informational processing constraints on management; moral hazard; rising political costs from divisions wastefully seeking preferential treatment; and, social comparison hazards, (e.g., Rawley 
and Simcoe 2010). The size of a 'bad' firm may even be bounded by its opportunity costs in terms of whether it could, once it reaches a large-enough scale or scope, actually add value through legal means more profitably than continuing to victimize society further, especially once it has grown large enough to own the necessary complementary assets (Teece 1986).

Moving from the more theoretical concepts to the more real, practical and behavioral perspective-based concepts, lie several further explanations for limits on the growth of a 'bad' firm. Given that such a firm breeds a culture of wrong-doing and treachery, it is likely to experience growing in-fighting, internal rent-shifting and -seeking, and self-interested obfuscation that all limit its growth. Further, there is likely a maximum distance from a 'glorious leader' or 'godfather' that can be tolerated up until employee loyalties fade sufficiently to cause fractures, coups, spinoffs or other limits to growth, unless violence is a viable enforcement mechanism. Additionally, with growth comes the increased probability of selecting sufficient numbers of people who actually have morals, and will limit firm size by opposing (or exposing) the increasing 'bad' activities. The growth of social harms perpetrated by the 'bad' firm also increases the likelihood of a government stepping in to stop it. Profitable growth also invites competition that limits the incumbent 'bad' firm's scale. Growth may even be restricted by capacity constraints that were contracted on in past collusive agreements with supply-chain partners. Additionally, in cases where the 'bad' firm is profiting through disinformation, eventually the costs of keeping track of the interconnected lies while protecting any set of truths required to continue internal operations are also likely to limit growth.

\section{Results}

We have drawn on materials from the literature to apply our theory-building methods to produce a new TotF. We can now describe the results, formally in terms of consequential propositions and less formally in terms of a discussion over the wider impacts and issues.

\section{Propositions}

Having met the two standard requirements for arguing a new TotF, we can now consider the main implications. Our new TotF describes the use of the firm form as a tool for doing well by doing bad, so it is important to understand the conditions under which the activities of such 'bad' firms are most likely to result in social harms. It is important because once those have been identified, there exists a greater possibility of mitigating such harms. The main conditions necessarily include not only the incentives for using the firm in this way but also the tolerance of that use in the firm's context. We know this because research has shown that the firm's 'tolerance context' - in terms of the incentives, rules and expectations, and their interactions-influence managerial behaviors (e.g., in tournament theory studies-see Kini and Williams 2012). Thus, our propositions will focus on the expected net rewards from 'doing bad', on the societal acceptance of such behaviors, and on their interactions, all in consideration of the realization of social harms. Figure 1 depicts the propositions and their connections.s 


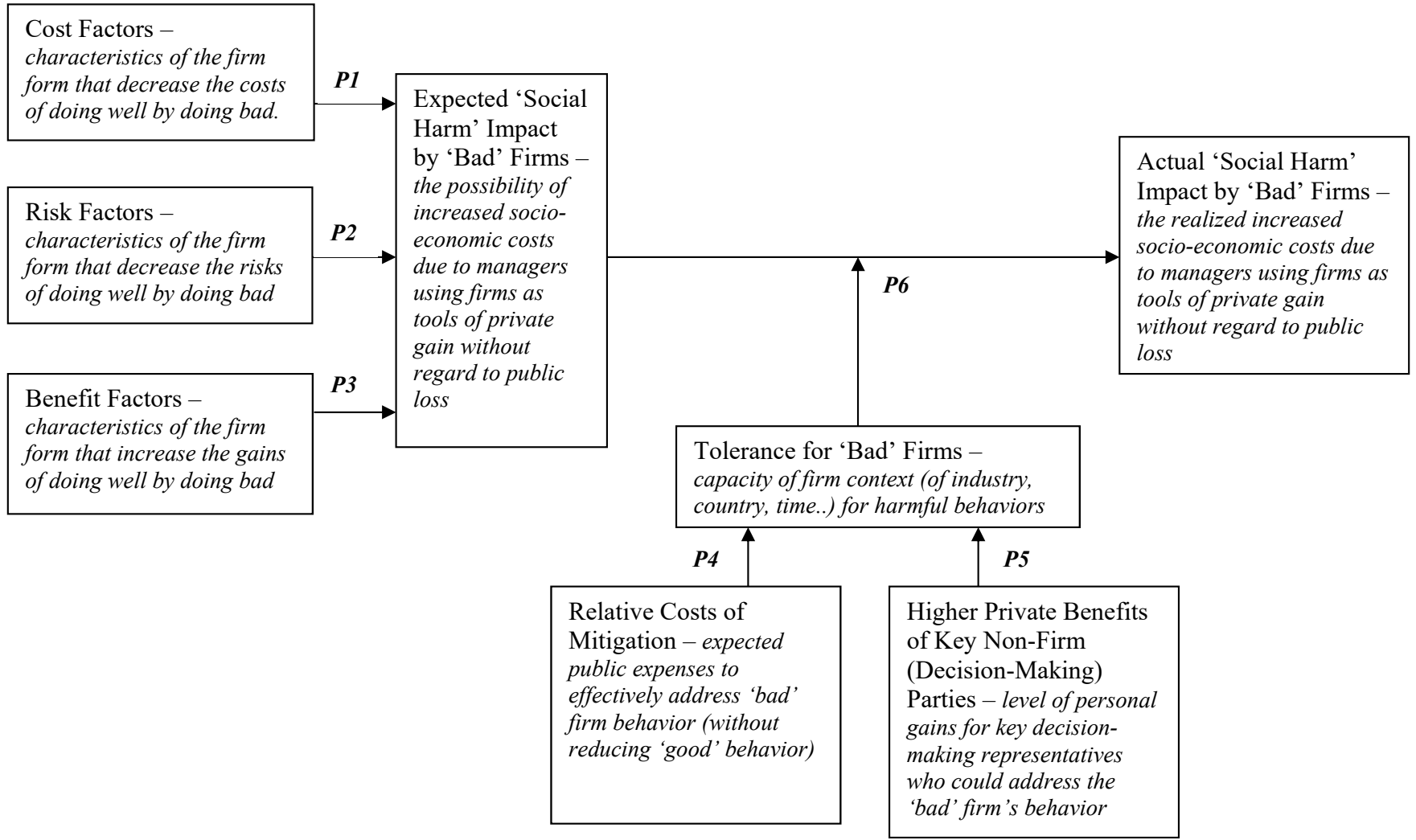

Figure 1. Mapping of the Propositions.

It is straightforward to identify the three main drivers that increase the incentives for managers to use their firms for doing well by doing bad. These are the same three drivers underlying rational decisions to partake in any activity and collectively produce its net expected benefits (i.e., the gross benefits, the gross costs, and the risks involved). As such, the possibility of increased socio-economic harm rises when the utilization of the firm form to profit from 'bad' activities can be accomplished with lower (private) costs, with lower (private) risks and with increased (private) benefits. Based on what we have described and argued above for meeting the first requirement for a TotF (delineated in the subsections), the first three propositions follow:

Proposition 1. Expected social harms will increase as the private costs for doing well by doing bad through the firm form decrease.

Proposition 2. Expected social harms will increase as the private risks for doing well by doing bad through the firm form decrease.

Proposition 3. Expected social harms will increase as the private benefits for doing well by doing bad through the firm form increase.

For 'bad' firms to turn their expected social harm-doing into realized social harmdoing requires the ability of the firm to pass society's scrutiny. The economic activities of these 'bad' firms must be tolerated by their contexts-made up of institutions, customers, partners, regulators, rivals and so forth-to actually do real harm. We argue that such tolerance is more likely when those harms are not considered as bad as they really are, at least to the parties who decide what is tolerated. That happens in three main circumstances: (i) when society is too distracted by the benefits of the firm form such that the costs of rooting out and punishing the 'bad' firms seems too high [e.g., as it may disturb the 
good works of other firms by burdening them with too regulations]; (ii) when society relies on those 'bad' firms to meet a legitimate-but-currently-illegal demand [like in era of the prohibition], or to meet a demand for products and services when its institutions have broken down [e.g., through the use of non-taxed barter, or through the provision of unregulated food and communications during times of crisis]; and, (iii) when the decisionmakers are few and otherwise ignorant or corruptible and often benefit from the activities of those firms in some way [e.g., through increased political donations]. In other words, the tolerance of possible social harms is more likely either when such harms are not seen as sufficiently 'bad' because the costs of addressing them are just too high, or when the private and often short-term benefits for decision-makers from the 'bad' firms are just too attractive (e.g., Dal Bó 2006; Gates and Jacob 2009; Pai and Tolleson 2012; Rogelj et al. 2013). The second two propositions follow:

Proposition 4. Tolerance for 'bad' firms is greater when their expected social harms are more costly to address.

Proposition 5. Tolerance for 'bad' firms is greater when their expected social harms entail higher private benefits for key institutional, political and community decision makers.

Contextual tolerance moderates the impact of 'bad' firm activities (e.g., Duffy et al. 2006; Garcia-Sanchez et al. 2014; Matthiesen and Salzmann 2017; Miska et al. 2018). Expected social harms only become realized social harms when doing well by doing bad is allowed to occur and continue. A bad apple only accesses and poisons the 'public market' when the bad barrel that contains it seems attractive enough to open. The effects of the incentives for doing well by doing bad through the firm form are moderated by the contextual effects of the disincentives for addressing those harms. Thus, the last proposition follows:

Proposition 6. Realized social harms are higher when greater expected social harms and greater social tolerance simultaneously exist.

\section{Discussion}

We proposed and argued for a new TotF that makes explicit that one of the significant reasons why the firm form exists is its superiority as a tool for doing well by doing bad. We explained that while the firm form is relatively better than the usual alternatives in such nefarious activities, fortunately there exist limits to the growth of any one such 'bad' firm. We built our TotF from basic premises about 'bads' existing in society and solid behavioral and economic logics (e.g., of market failure types) to outline what these nefarious firms do and how they are good at doing it. From this new TotF, we generated several propositions relating the incentives for doing 'bad' to the expected social harms, and then relating the moderating effects of contextual tolerance of such activities to the realized social harms. Our TotF embodies a solid contribution to the literatures on firm theory and on dark side entrepreneurship. Furthermore, our analysis provides a solid basis for conversations about what firms 'should be', relative to what they are and what they can be, along the directions of social entrepreneurship and corporate social responsibility research (e.g., Mair and Noboa 2006; Porter and Kramer 2006). Our underlying moral stance has been based on care and fairness (and cuts across means and ends), focusing on the disutility caused by those using firms for their private gains. Our academic stance has been that such a TotF is needed in order to highlight such dangers; because, if we can prove that one reason that the firm form exists is because it is better at doing bad, then more attention, policies and resources can be drawn upon to ensure it does not.

It is important to understand that our TotF is not simply complementary of other TotFs in terms of adding to the list of the many separate relative 'advantages' of the firm form. Instead, it is distinct in being critical and negative. It extends beyond the idea that this organizational form can be used to increase private wealth at public expense (e.g., through trying to exploit market power) in some detached, only-detrimental-to-faceless-consumers, 
easy-to-recognize-and-fix-through-standard-policies way. The social harms possible for firms to wreak upon their victims are often quite targeted, mean, and have little chance of quick-and-painless counter-measures. Firms are built to exploit existing 'asymmetries of evil' (e.g., Arend 2015), and to do so at scale. As such, a firm is not a 'neutral' tool; it has especially nasty effects in negative applications (Our TotF questions a central idea in management-that, without the benefits from skills-based specialization, there is no need for firms to exist. Our TotF does not require skilled specialists to provide firm profitability; instead, it can just cheat, and use the hierarchy to cover that up. Further, we are not blaming the firm form for social harm (akin to blaming ships for the activity of piracy), but we are blaming the scale, scope, and unaccountability of social harm on that form (akin to blaming the actual devastation of a nuclear weapon's outcome on the nuclear weapon)). The firm form can be used in many ways to combine authority, high-powered emotional rewards (e.g., revenge), threats, secrecy, faux-legitimacy, and scale in order to coordinate, to control and to gain compliance of many relevant parties both inside and outside of its formal boundaries, in order to gain private benefits for itself and its supporters while damaging others who stand in the way, like whistle-blowers (e.g., Rehg et al. 2008). Indeed, one reason for the many variants in the structure of nefarious firms may well be based on which of these enabling traits the specific firm gains the most from (e.g., unaccountability [through economies of opaqueness]; power [to abuse]; size [to benefit from specialization]; blind loyalty [to protect leaders]; or, social division [to make it easier to harm outsiders]).

While our TotF depicts the nefarious functions of firms, all other TotFs depict the beneficial functions of the firm. Therefore, even though firms, or their managers acting in their own and their firm owners' interests, are capable of doing bad and are often actually culpable of so doing, it appears that firms are most often used as a tool to create social benefits (e.g., Argandoña 1998; McWilliams and Siegel 2001). The belief that the firm form will continue to be mostly used in a 'good' manner is one of the main reasons why the firm form is tolerated. Normally, the firm is expected to be wielded by its manager in a manner that meets her obligations under existing social contracts by providing fair returns to, and fair treatment of, major stakeholders, including her employees and the local community. Bottom line, then, the solution to the existence of 'bad' firms is not the wholesale elimination of the firm form.

Our TotF entails implications for both academia and for practice. Given the latter implies potentially helping nefarious managers further misuse that tool, we will focus only the former (That said, 'good' managers may be able to use our descriptions of abuses of the firm form, as identified in our TotF analysis, to better understand and fight against 'bad' managers in their own firms, and to avoid 'bad' firms that may be potential business partners or rivals.). It is our responsibility, as scholars, in our roles as business tool-makers and tool-analyzers, to proactively point out the risks and signs of tool misuse, and to offer some remedies. Therefore, first, when we speak of the good that firms can do, we need to do a better job of acknowledging the too-often-occurring bad as well; and one way is to take more seriously the problems that occur when organizational incentives are not aligned with society's (e.g., Ghoshal 2005). Additionally, secondly, we need to do more research on identifying and addressing misuses of the firm form. Although more difficult to study and to publish on, we need to build better early warning measures of firm behaviors that lead to doing social harm. We need to construct paths that support entrepreneurship that displaces not only inefficient but also the more 'socially bad' firms. We need to build better pro-social-responsibility incentives and better policies that require accountability and transparency when firms scale or scope up.

As with other TotFs, the description and arguments of our new TotF imply several relationships that are testable. Primarily, the six propositions could be tested once empirical measures for the costs, benefits, risks, harms of relevant parties are established. This may be easier when industries, time periods and national contexts can be specified where such measures are already being taken, and where some history of harms (e.g., from pollution) has been recorded. Case studies may also be appropriate to provide details on how the 
abuse of the firm form progresses, and whether it is moderated by the firm's contexts (e.g., Levitt and Venkatesh 2000). Besides testing our six propositions, it may also be valuable to test the standard TotF-related decision - the decision over which alternative governance form to choose when. For example, based on our TotF, we expect to find more lawsuit activity, more whistle-blower activity, and more formal reports of bad activity, especially at scale, in more hierarchical governance structures, like firms.

We recognize several limitations associated with our proposed TotF. We have assumed a 'western' economic context here where, for example, managers can use the tool of the firm in socially harmful ways, at least temporarily, and without fear of death, or other harsh circumstances, because they are not controlled by a government, and where whistleblowing is of interest to a free press. Therefore, while the basic mechanics of the TotF remain, the span and examples described will not be applicable globally. We have also assumed a stable understanding of what 'bad' is; but given social norms evolve over space and time, as do our technical abilities to identify harms, the meaning of the main dependent variable here is bounded by a meta-context. That stability assumption also involves the somewhat 'static' nature of our model. A more dynamic depiction could include feedback loops, where the firm's activities influence contextual tolerance, and the environment affects a manager's choice to use the tool for 'bad' (e.g., Nadkarni and Barr 2008). Further, we have assumed a bimodal classification of the use of the 'firm form' as a tool of either 'bad' or 'good'. Obviously, there exists more real-world subtlety to the extent, target, and frequency of the use of the tool for doing 'bad'.

There are several things that can be done to help ensure that the benefits of the firm form are more often experienced than the harms: Increasing the expected costs from 'doing bad' is an obvious step, and that means increasing both the probability of getting caught and its penalty. That means having clear, consistent and international standards of behavior that are closely monitored by trusted, un-corruptible parties. Additionally, that means altering the laws to hold executives accountable by forcing them to sign statements of responsibility, and to ensure that they serve real jail-time for white-collar crimes, especially at the executive level, when they violate such responsibilities. It also means campaign finance and other political and judicial reform to ensure no undue influence occurs that would weaken oversight, enforcement and sentencing. It also means stronger whistleblower protections and rewards, and the need for independent, external parties to be involved in the investigations of concerns exposed by whistle-blowers. It means stronger transparency laws and restrictions on non-disclosure agreements (e.g., Heath 2014). It means more auditing beyond the financial, by using external, trusted agents open to criminal and reputational harms if they are corrupted. Regardless of the steps taken, more discussion of the implications of this nefarious TotF needs to be undertaken by the academic, policy and practitioner communities in order to ensure that the tradeoffs over the types of governance forms we legalize, and the types of constraints we place them under, are well understood and fairly accepted.

\section{Conclusions}

A new TotF now exists that describes the superiority of the firm form in doing well by doing bad. It also explains why the growth of any one such 'bad' firm is thankfully limited. It leads to testable propositions relating to when potential and realized social harms are more likely to occur. As a result, this new TotF offers a welcome counter-balance to the existing set of TotFs that have mostly ignored the downsides of the firm form that too many in society experience too often.

This new TotF describes particular mechanisms that the firm form offers so that its managers can do specific harms with higher private benefits at lower private risks and costs. The TotF explains the economies that the firm form provides to scale such socially detrimental activities up and out (prior to reaching size limits that are also explained). The TotF describes the specific types of societal harms and the likely victims and enablers involved. That understanding then provides a basis for mitigating the misuse of the firm 
form, and for appreciating the challenges that such a 'pushback' involves (e.g., culturally, regulatorily, and so on).

It is hoped that the revelations revealed in this paper are heeded, so that powerful economic tools like the firm form are applied more wisely, transparently and responsibly in the future.

Funding: This research received no external funding.

Institutional Review Board Statement: Not applicable.

Informed Consent Statement: Not applicable.

Data Availability Statement: Not applicable.

Conflicts of Interest: The author declares no conflict of interest.

\section{References}

Akerlof, George A. 1970. The Market for Lemons: Quality Uncertainty and the Market Mechanism. Quarterly Journal of Economics 84: 488-500. [CrossRef]

Alchian, Armen A., and Harold Demsetz. 1972. Production, information costs, and economic organization. The American Economic Review 62: 777-95.

Al-Shammari, Marwan, Abdul Rasheed, and Hussam A. Al-Shammari. 2019. CEO narcissism and corporate social responsibility: Does CEO narcissism affect CSR focus? Journal of Business Research 104: 106-17. [CrossRef]

Arend, Richard J. 2006. SME-supplier alliance activity in manufacturing: Contingent benefits and perceptions. Strategic Management Journal 27: 741-63. [CrossRef]

Arend, Richard J. 2015. Wicked Entrepreneurship: Defining the Basics of Entreponerology. New York: Palgrave Macmillan.

Argandoña, Antonio. 1998. The stakeholder theory and the common good. Journal of Business Ethics 17: 1093-102. [CrossRef]

Ashrafi, Mehrnaz, Gregory M. Magnan, Michelle Adams, and Tony R. Walker. 2020. Understanding the conceptual evolutionary path and theoretical underpinnings of corporate social responsibility and corporate sustainability. Sustainability 12: 760. [CrossRef]

Bain, Joe S. 1951. Relation of profit rate to industry concentration: American manufacturing, 1936-1940. The Quarterly Journal of Economics 65: 293-324. [CrossRef]

Bain, Joe S. 1954. Economies of scale, concentration, and the condition of entry in twenty manufacturing industries. The American Economic Review 44: 15-39.

Ball, George P., Rachna Shah, and Karen Donohue. 2018. The decision to recall: A behavioral investigation in the medical device industry. Journal of Operations Management 62: 1-15. [CrossRef]

Baucus, Melissa S., and Cheryl R. Mitteness. 2016. Crowdfrauding: Avoiding Ponzi entrepreneurs when investing in new ventures. Business Horizons 59: 37-50. [CrossRef]

Baumol, William J. 1990. Entrepreneurship: Productive, Unproductive, and Destructive. Journal of Political Economy 98: 893-921. [CrossRef]

Cai, Ye, Hoje Jo, and Carrie Pan. 2012. Doing well while doing bad? CSR in controversial industry sectors. Journal of Business Ethics 108: 467-80. [CrossRef]

Cohen, Jeffrey, Yuan Ding, Cédric Lesage, and Hervé Stolowy. 2012. Corporate fraud and managers' behavior: Evidence from the press. In Entrepreneurship, Governance and Ethics. Dordrecht: Springer, pp. 271-315.

Connelly, Brian L., Laszlo Tihanyi, S. Trevis Certo, and Michael A. Hitt. 2010. Marching to the beat of different drummers: The influence of institutional owners on competitive actions. Academy of Management Journal 53: 723-42. [CrossRef]

Conner, Kathleen R. 1991. A historical comparison of resource-based theory and five schools of thought within industrial organization economics: Do we have a new theory of the firm? Journal of Management 17: 121-54. [CrossRef]

Cressey, Donald Ray. 1973. Other People's Money. Montclair: Patterson Smith.

Cyert, Richard M., and James G. March. 1963. A Behavioral Theory of the Firm. Englewood Cliffs: Prentice-Hall.

Dal Bó, Ernesto. 2006. Regulatory capture: A review. Oxford Review of Economic Policy 22: 203-25. [CrossRef]

Duffy, Michelle K., Daniel C. Ganster, Jason D. Shaw, Jonathan L. Johnson, and Milan Pagon. 2006. The social context of undermining behavior at work. Organizational Behavior and Human Decision Processes 101: 105-26. [CrossRef]

Elert, Niklas, and Magnus Henrekson. 2016. Evasive entrepreneurship. Small Business Economics 47: 95-113. [CrossRef]

Garcia-Sanchez, Isabel-Maria, Beatriz Cuadrado-Ballesteros, and Cindy Sepulveda. 2014. Does media pressure moderate CSR disclosures by external directors? Management Decision 52: 1014-45. [CrossRef]

Gates, Tiffany, and Katy Jacob. 2009. Payments Fraud: Perception Versus Reality-A conference summary. Economic Perspectives 33: 7-15.

Ghoshal, Sumantra. 2005. Bad Management Theories Are Destroying Good Management Practices. Academy of Management Learning E Education 4: 75-91.

Grant, Robert M. 1996. Towards a knowledge-based theory of the firm. Strategic Management Journal 17: 109-22. [CrossRef] 
Heath, Joseph. 2014. Morality, Competition, and the Firm: The Market Failures Approach to Business Ethics. Oxford: Oxford University Press.

Hmieleski, Keith M., and Daniel A. Lerner. 2016. The dark triad and nascent entrepreneurship: An examination of unproductive versus productive entrepreneurial motives. Journal of Small Business Management 54: 7-32. [CrossRef]

Holmstrom, Bengt R., and Jean Tirole. 1989. The theory of the firm. Handbook of Industrial Organization 1: 61-133.

Kini, Omesh, and Ryan Williams. 2012. Tournament incentives, firm risk, and corporate policies. Journal of Financial Economics 103: 350-76. [CrossRef]

Kirzner, Israel M. 2009. The alert and creative entrepreneur: A clarification. Small Business Economics 32: 145-52. [CrossRef]

Lange, Donald, and Nathan T. Washburn. 2012. Understanding attributions of corporate social irresponsibility. Academy of Management Review 37: 300-26. [CrossRef]

Levitt, Steven D., and Sudhir Alladi Venkatesh. 2000. An economic analysis of a drug-selling gang's finances. The Quarterly Journal of Economics 115: 755-89. [CrossRef]

Lewis, Michael. 2015. Flash Boys: Cracking the Money Code. London: Penguin Books.

Lim, Elizabeth N. K., and Brian T. McCann. 2013. Performance Feedback and Firm Risk Taking: The Moderating Effects of CEO and Outside Director Stock Options. Organization Science 25: 262-82. [CrossRef]

Lovelace, Jeffrey B., Jonathan Bundy, Donald C. Hambrick, and Timothy G. Pollock. 2018. The Shackles of CEO Celebrity: Sociocognitive and Behavioral Role Constraints on "Star" Leaders. Academy of Management Review 43: 419-44. [CrossRef]

Lucas, David S., and Caleb S. Fuller. 2017. Entrepreneurship: Productive, unproductive, and destructive-Relative to what? Journal of Business Venturing Insights 7: 45-49. [CrossRef]

Lumpkin, G. Tom, and Gregory G. Dess. 1996. Clarifying the Entrepreneurial Orientation Construct and Linking it to Performance. Academy of Management Review 21: 135-72. [CrossRef]

Lundmark, Erik, and Alf Westelius. 2019. Antisocial entrepreneurship: Conceptual foundations and a research agenda. Journal of Business Venturing Insights 11: e00104. [CrossRef]

Mair, Johanna, and Ernesto Noboa. 2006. Social entrepreneurship: How intentions to create a social venture are formed. In Social Entrepreneurship. London: Palgrave Macmillan, pp. 121-35.

Matten, Dirk, Andrew Crane, and Wendy Chapple. 2003. Behind the mask: Revealing the true face of corporate citizenship. Journal of Business Ethics 45: 109-20. [CrossRef]

Matthiesen, Marie-Louise, and Astrid Juliane Salzmann. 2017. Corporate social responsibility and firms' cost of equity: How does culture matter? Cross Cultural and Strategic Management 24: 105-24. [CrossRef]

McWilliams, Abagail, and Donald Siegel. 2001. Corporate social responsibility: A theory of the firm perspective. Academy of Management Review 26: 117-27. [CrossRef]

Michelon, Giovanna, Silvia Pilonato, and Federica Ricceri. 2015. CSR reporting practices and the quality of disclosure: An empirical analysis. Critical Perspectives on Accounting 33: 59-78. [CrossRef]

Miska, Christof, Günter K. Stahl, and Matthias Fuchs. 2018. The moderating role of context in determining unethical managerial behavior: A case survey. Journal of Business Ethics 153: 793-812. [CrossRef]

Nadkarni, Sucheta, and Pamela S. Barr. 2008. Environmental context, managerial cognition, and strategic action: An integrated view. Strategic Management Journal 29: 1395-427. [CrossRef]

O'Connor, Clare. 2014. Report: Walmart workers cost taxpayers $\$ 6.2$ billion in public assistance. Forbes, April 15.

Oh, Hannah, John Bae, and Sang-Joon Kim. 2017. Can sinful firms benefit from advertising their CSR efforts? Adverse effect of advertising sinful firms' CSR engagements on firm performance. Journal of Business Ethics 143: 643-63. [CrossRef]

Orts, Eric W. 1998. Shirking and sharking: A legal theory of the firm. Yale Law and Policy Review 16: $265-329$.

Pai, Kalpana, and Thomas D. Tolleson. 2012. The capture of government regulators by the big 4 accounting firms: Some evidence. Journal of Applied Business and Economics 13: 84-94.

Palmer, Donald, Royston Greenwood, and Kristin Smith-Crowe. 2016. Organizational Wrongdoing: Key Perspectives and New Directions. Cambridge: Cambridge University Press.

Petrenko, Oleg V., Federico Aime, Jason Ridge, and Aaron Hill. 2016. Corporate social responsibility or CEO narcissism? CSR motivations and organizational performance. Strategic Management Journal 37: 262-79. [CrossRef]

Porter, Michael E., and Mark R. Kramer. 2006. The link between competitive advantage and corporate social responsibility. Harvard Business Review 84: 78-92.

Rawley, Evan, and Timothy S. Simcoe. 2010. Diversification, diseconomies of scope, and vertical contracting: Evidence from the taxicab industry. Management Science 56: 1534-50. [CrossRef]

Rehg, Michael T., Marcia P. Miceli, Janet P. Near, and James R. Van Scotter. 2008. Antecedents and outcomes of retaliation against whistleblowers: Gender differences and power relationships. Organization Science 19: 221-40. [CrossRef]

Rogelj, Joeri, David L. McCollum, Andy Reisinger, Malte Meinshausen, and Keywan Riahi. 2013. Probabilistic cost estimates for climate change mitigation. Nature 493: 79-83. [CrossRef]

Schumpeter, Joseph A. 1934. The Theory of Economic Development. Oxford: Oxford University Press.

Teece, David J. 1986. Profiting from technological innovation: Implications for integration, collaboration, licensing and public policy. Research Policy 15: 285-305. [CrossRef]

Tirole, Jean. 1988. The Theory of Industrial Organization. Boston: MIT press. 
Webb, Justin W., Laszlo Tihanyi, R. Duane Ireland, and David G. Sirmon. 2009. You say illegal, I say legitimate: Entrepreneurship in the informal economy. Academy of Management Review 34: 492-510. [CrossRef]

Wernerfelt, Birger. 1984. A resource-based view of the firm. Strategic Management Journal 5: 171-80. [CrossRef]

Williamson, Oliver E. 1979. Transaction-cost economics: The governance of contractual relations. Journal of Law and Economics 22 233-61. [CrossRef]

Zahra, Shaker A., and Mike Wright. 2016. Understanding the social role of entrepreneurship. Journal of Management Studies 53: 610-29. [CrossRef] 